Revue Française de Civilisation Britannique

XXIII-3 | 2018

A Long Awakening? Environmental Concerns in the United Kingdom Since the Nineteenth Century

\title{
Brexit and UK Environmental Policy and Politics
}

Le Brexit et la question environnementale au Royaume-Uni

\section{Charlotte Burns and Neil Carter}

\section{(2) OpenEdition}

1 Journals

Electronic version

URL: http://journals.openedition.org/rfcb/2385

DOI: $10.4000 /$ rfcb.2385

ISSN: 2429-4373

Publisher

CRECIB - Centre de recherche et d'études en civilisation britannique

\section{Electronic reference}

Charlotte Burns and Neil Carter, "Brexit and UK Environmental Policy and Politics », Revue Française de Civilisation Britannique [Online], XXIII-3 | 2018, Online since 07 December 2018, connection on 08 January 2020. URL : http://journals.openedition.org/rfcb/2385 ; DOI : 10.4000/rfcb.2385

This text was automatically generated on 8 January 2020.

\section{(c) $($ ) $\odot$ (8Y NO}

Revue française de civilisation britannique est mis à disposition selon les termes de la licence Creative Commons Attribution - Pas d'Utilisation Commerciale - Pas de Modification 4.0 International. 


\title{
Brexit and UK Environmental Policy and Politics
}

\author{
Le Brexit et la question environnementale au Royaume-Uni
}

Charlotte Burns and Neil Carter

\section{Introduction}

On 23 June 2016 the United Kingdom (UK) held a referendum on European Union (EU) ${ }^{1}$ membership. By a margin of $52 \%$ to $48 \%$ the British public voted to leave the EU, although there were some notable geographic patterns to the vote: while $62 \%$ of voters in Scotland and $56 \%$ in Northern Ireland supported remain, $52.5 \%$ of the electorate in Wales and 53.4\% in England voted to leave. The political fallout was immediate: Prime Minister David Cameron resigned and, following a short leadership contest, Theresa May emerged unchallenged as the new leader of the Conservative Party and Prime Minister. The Article 50 process was triggered on 29 March 2017; then, unexpectedly, May called an election, with the intention of increasing the Conservatives' majority and thereby strengthening her hand in the Brexit negotiations. However, after a disastrous election campaign May actually lost her majority and had to turn to the Northern Irish Democratic Unionist Party to prop up her government in parliament through a 'confidence and supply agreement'. Moreover, she now presided over a divided party and a fractious cabinet.

2 The environment did not feature significantly in the debates leading up to the referendum, which focussed mainly on national sovereignty, immigration and the economy. Nor was it prominent in the 2017 election campaign. However, because UK environmental policy has been profoundly shaped by its EU membership, the environment has emerged as a major issue as the Brexit process has unfolded. A recent government review of the anticipated impact of Brexit on departmental work found that the Department for Environment Food and Rural Affairs (Defra) will be the second most Brexit-affected department because $80 \%$ of its work is EU related. ${ }^{2}$ A tranche of studies have identified the many challenges associated with repatriating the environmental acquis and its associated governance infrastructure, and they have raised important 
questions about the long term implications of Brexit for the ambition and stability of UK environment policy. ${ }^{3}$ There are also wider party political implications - there has been a move on the right to couple euro-sceptic with anti-environment rhetoric by attacking EU environmental regulations, which have been characterised as 'green tape'. This move has politicised environmental policy in ways that may create instability in a policy sector where long-term strategic planning and stability are essential for the achievement of key goals such as decarbonisation. The nature of environmental policy as a devolved policy sector also raises crucial wider constitutional questions about the relationship between Westminster and the devolved nations. We conclude that even though considerable uncertainty remains about the final outcomes of the Brexit process, on balance it is likely to have negative implications for UK environmental policy.

\section{From Dirty Man of Europe to Limited Leader}

3 When the UK joined the EU in 1973 the UK Government did not anticipate that EU membership would exert much influence upon domestic environmental policy. British civil servants were of the view that the UK had a long and successful tradition of environmental policy dating back to the 1863 Alkali Inspectorate. It was assumed that the UK had little to learn and little to change as a consequence of joining the EU. ${ }^{4}$ However, it rapidly became apparent that the predominant style of UK policy making was different from that used by other EU states, and that the habits and traditions that characterised British policy were inconsistent with the emerging EU policy style. The UK had traditionally preferred to regulate via negotiated consent with informal agreements between the government and those being regulated. This voluntarist approach was at odds with the uniform emission standards and regulations backed up in law, preferred by

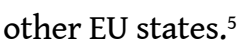

4 The Department for Environment (DoE) ${ }^{6}$ initially struggled to cope with the demands of EU membership for it was slow to realise that being obstructive in negotiations did not prevent policy being adopted and increased the scope for policy misfit down the line, resulting in the UK facing a series of court cases for the non-implementation of EU laws. ${ }^{7}$ However, by the 1990s the DoE began to 'think European' and started to engage more positively with Brussels, seeking to upload key policy ideas such as environmental policy integration, integrated pollution control and eco-auditing. ${ }^{8}$ The UK was transformed from being a taker of EU policy to proactively trying to shape policy in order to minimise the costs of compliance, ${ }^{9}$ to the extent that in the 2000s the UK became a key voice on climate change at the European level, providing a leadership role and acting as a counterweight to more climate-sceptic states within the Council. ${ }^{10}$

5 Thus, overall, the EU has had a profound 'Europeanizing' effect upon UK environmental policy by forcing a change in the preferred voluntarist style towards a more regulated and transparent approach, and encouraging the UK to engage actively and positively with EU decision-making processes. ${ }^{11}$ However, patterns of Europeanization have been variegated: in water and air policy the changes were profound and required significant investment, whereas in land-use planning the EU had a more limited effect. ${ }^{12}$ This variegation suggests that the impact of Brexit upon UK policy styles and practice will be similarly differentiated. It is likely that where significant changes and investments have been made in infrastructure (water, air quality, renewables) stability, at least in the short to medium term, is more likely. But where completely new policies are required 
(agriculture and fisheries), or where Europeanization has been less profound, the scope for change may be greater.

\section{The Impact of the EU on the Party Politics of the Environment}

Whilst the EU has shaped UK environmental policy in profound ways it initially exerted little direct influence on the party politics of the environment. However, in recent years the coupling of enviro-sceptic and euro-sceptic rhetoric on the right has led to a heightened politicisation of EU environmental politics and policy within the UK in ways that are shaping post-Brexit debates on environmental governance.

7 Since the 1980s the two major parties have undergone a slow and limited politicisation of the environment. While no party can afford to ignore the issue, the Conservative and Labour parties have both pursued a strategy of preference-accommodation, characterised by a reactive approach to public opinion, but largely resisting competition over the environment. ${ }^{13}$ Developments in the EU have occasionally encroached on this process. For example, in the 1980s the UK was derided as the 'Dirty Man of Europe' for its failure to implement EU environmental policy and this epithet enabled Labour and the Liberal Democrats to score political points against the Conservative Government. Elections to the European Parliament also raised the profile of the Green Party, particularly after the introduction of proportional representation enabled the election of Green MEPs in 1999.

There was, however, a step-change in 2006, which heralded unprecedented party competition over climate change and encouraged the major parties to shift their positions. This 'competitive consensus'14 amongst the parties enabled the Labour Government, with cross-party support, to transform climate and energy policy by introducing the landmark Climate Change Act 2008 (CCA), which established ambitious long term emission reduction targets on a statutory basis, five-yearly carbon budgets and an independent Climate Change Committee with a remit to advise the government on the policies needed to achieve these targets. ${ }^{15}$ The CCA was followed by a tranche of policy measures on renewable energy, feed-in tariffs, infrastructure planning and domestic energy efficiency, supported by significant public investment.

The opening of this 'window of opportunity' for policy change can be explained by several developments, notably growing public concern about climate change, Friends of the Earth's 'The Big Ask' campaign calling for a CCA, David Cameron's decision to make the environment the centrepiece of his strategy to modernise the Conservative Party and the success of the Stern Review in galvanising business support for action on climate change. ${ }^{16}$ The EU contributed to these developments by acting as an external policy driver sustaining the political momentum behind the CCA. In particular, the March 2007 European Council agreement on new climate and energy targets for 2020 included the challenging target that $15 \%$ of all UK energy should come from renewable sources, which effectively compelled the Government to adopt a significantly more interventionist energy policy requiring new and increased subsidies, new industrial incentives and a new planning regime. ${ }^{17}$

10 Thus, during this period of a competitive consensus EU membership played a positive role in encouraging parties to strengthen their environmental credentials and to compete with their rivals on environmental issues. However, as the effects of the economic crisis 
started to bite, both the EU and its environmental policy became the focus of fierce criticism from right wing politicians and media; in particular, climate scepticism joined a wider Conservative frame encompassing anti-EU, anti-regulation and anti-tax views. While the consensus among party leaders in favour of progressive climate policy was just about sustained during the 2010-2015 Coalition Government, the broader consensus began to disintegrate. Thus the decision to adopt the $4^{\text {th }}$ carbon budget in 2011 became the site of conflict between Chris Huhne, the Liberal Democrat Secretary of State for Energy and Climate Change, and Conservative Chancellor George Osborne, who was concerned that economic competitiveness might be harmed if the UK moved faster to reduce its emissions than other EU members. Eventually Prime Minister Cameron intervened to ensure the budget was approved (subject to a review in 2014), arguing it was essential if the UK was to meet its EU target of a $34 \%$ reduction in GHG emissions. ${ }^{18}$ Meanwhile, among Conservative MPs there was growing - and often vitriolic - criticism of specific climate policies, such as the growth of onshore wind and the green levies imposed on electricity bills. ${ }^{19}$

11 In this same period the Government launched a review of the UK's implementation of EU habitats and birds directives to address concerns that the UK was overly enthusiastic in implementing them (so-called gold-plating) and that they were an expensive obstacle to growth. ${ }^{20}$ The review found that the directives were fit for purpose but there was a growing rhetoric around the imposition of costly EU regulations. ${ }^{21}$ The Government launched a red tape challenge in 2011 to eradicate 'burdensome' regulations and expressed irritation that much of the so-called red tape that it wanted to get rid of emanated from the EU and could not therefore be cut. ${ }^{22}$

Given the profound Europeanization of this policy sector and the growth of a negative discourse around EU 'green tape', it is perhaps surprising that environmental policy enjoyed limited salience during the referendum campaign. Cameron made one major speech $^{23}$, but otherwise the issue had little traction. Subsequently, as the scale of the Brexit task and the huge implications for Defra became clear, the environment became a major focus of post-referendum work and lobbying, to which we turn in the following section.

\section{Brexit and UK Environmental Policy}

13 In the immediate aftermath of the referendum a key fear articulated by green groups was that Brexit would lead to weaker environmental standards. In particular, they pointed out that the process of leaving the EU could lead to i) regulatory gaps in UK environmental policy; ii) governance gaps; iii) poor co-ordination and policy incoherence across the UK; and iv) deliberate policy retrenchment (given the negative rhetoric around EU environmental policies). In this section we explain the problems associated with each issue, how the Government has sought to address these challenges and evaluate how successful its strategy has been or is likely to be (at the time of writing many issues remain unresolved).

\section{Regulatory Gaps and the EU Withdrawal Bill}

14 One early concern was the status of environmental regulations post-Brexit. EU directives are incorporated into UK law via domestic legislation and will therefore remain in place 
once the UK leaves the EU. However, EU regulations have been incorporated into UK law via article 2 (2) of the European Communities Act (ECA) of $1972^{24}$ and there was concern that, as the ECA will be repealed when the UK leaves the EU, any regulations given legal force in the UK under the provisions of article 2(2) would cease to apply. As many of those regulations have been adopted to update directives there was scope for numerous regulatory gaps emerging in UK law. To address this risk the Government brought forward an EU Withdrawal Bill (EUWB) that will convert all EU law into 'retained EU law' to prevent legal loopholes and regulatory gaps emerging on exit day. ${ }^{25}$ The Bill was highly controversial due to the powers it awards government to change law without input from parliaments in the UK (at Westminster, Holyrood, Cardiff Bay and Stormont) and for its implications for the UK's constitutional settlement (see below).

Moreover, there was also concern that some important elements of EU environmental law would not be carried over, such as the environmental policy principles that are articulated in the EU Treaties. For example, Article 3 of the Treaty on European Union commits the EU to the pursuit of a high level of environmental protection, and Article 191 (2) of the Treaty on the Functioning of the EU (TFEU) states that EU environmental policy should be based upon the prevention, polluter pays, precautionary and proximity principles. The Government launched a consultation to gather views on how to address this gap in Spring 2018 with a bill anticipated in early 2019. In parallel, during the debates on the EUWB, an amendment was adopted stipulating that the Government bring forward a bill within six months containing environmental principles and listing those that should be included. ${ }^{26}$ This amendment was adopted partly due to on-going scepticism about the Government's genuine commitment to the environmental policy principles. After several close votes and some parliamentary 'ping-pong' between the House of Commons and the House of Lords, the Government managed to get the EUWB adopted, putting in place the first stepping stone to Brexit. ${ }^{27}$ Its adoption means that most of the potential regulatory gaps, including the principles gap, should now be addressed, although there is widespread apprehension about the magnitude of the task of reviewing all EU law that will be carried over into UK law.

\section{Governance Gaps}

16 Alongside the potential regulatory gaps there is the possibility that Brexit could create significant environmental governance gaps. Currently, there is EU involvement throughout the UK policy cycle: developing policy, providing expertise and data gathering, monitoring, implementation and enforcement. ${ }^{28}$ The UK benefits from being able to draw upon expertise from the European Commission and a range of agencies, including the European Environment Agency and the European Chemicals Agency, and from other EU states. ${ }^{29}$ These repositories of expertise and innovation are unlikely to be readily available post-Brexit.

The UK is also obliged to provide regular reports to the Commission on its ability to deliver against targets, which are then made publicly available. These transparent reporting practices mean that citizens, NGOs and other groups can hold governments to account if they have failed to meet targets or deliver on policy goals. Finally, in the event of on-going implementation and enforcement lapses states can be prosecuted under EU law and may eventually find their case being referred to the Court of Justice of the EU (CJEU). The UK is taken to the CJEU relatively rarely compared to other states, but 
environmental issues are those that most often see the UK facing EU legal action. Moreover, whilst the UK tends to win most cases, in the field of environmental policy it has lost 21 out of 25 cases since 2003, ${ }^{30}$ which suggests the CJEU has provided an important route for securing environmental policy implementation in the UK.

To address this issue the government consultation launched in May $2018^{31}$ also covered environmental governance and proposed the creation of a new environmental watchdog to replace some of the functions that currently reside with the CJEU and European Commission. However, these proposals have been widely condemned as offering an inadequate substitute for the EU's enforcement regime, as the watchdog's role would be largely advisory and there is currently no scope for fining the Government as a last resort..$^{32}$ Yet the Environment Secretary's scope (let alone his willingness) to respond to such criticisms may be limited by the opposition of the Treasury, which regards the watchdog as a potential threat to economic competitiveness, ${ }^{33}$ and there is wider political resistance to establishing a body that can levy fines against the government. Thus, despite the Government's promise to create a powerful watch-dog, the new body seems unlikely to fill the environmental governance gaps created by Brexit.

\section{Coordination, Coherence and Devolution}

Brexit has also highlighted the asymmetrical nature of the UK's devolution settlement. The UK Government devolved substantial powers to Scotland, Wales and Northern Ireland in 1998 and environment, agriculture and fisheries are all devolved policy areas. As an EU member subject to Article 193 [TFEU], the so-called Environmental Guarantee article, all the UK's devolved administrations are tied to the same minimum EU standards but individual administrations can pursue more advanced policies should they wish to do so. Indeed, there has been upward divergence in some policy sectors in the UK. For example, Scotland and Wales have more ambitious climate policies than England, ${ }^{34}$ while Wales has ambitious waste policies, a sustainable development agenda and a Future Generations Commissioner. By contrast, environmental policy has limited salience in Northern Ireland, where many recent environmental gains have been due to pressure from the EU and where there is a real possibility that Brexit could lead to lower standards with concomitantly negative implications for the Republic of Ireland. Moreover, with no government in Northern Ireland at the time of writing Stormont has no voice at the table in the on-going negotiations about the future of UK environmental policy. The 'confidence and supply' relationship between the DUP and the Conservatives does provide an opportunity for Northern Irish input, but it is not unproblematic as this informal relationship privileges just one of the two major Northern Irish parties, with little in the way of formal scrutiny or accountability.

The absence of the EU framework setting common minimum standards raises the prospect of a regulatory "race to the bottom" and policy incoherence across the UK. One solution would involve the four nations agreeing a minimum floor for environmental policy similar to that provided currently by the EU. But this option has become mired in political controversy over who will decide what those minimum standards should be, with tensions stoked by the UK Government's handling of the EUWB process. The EUWB stipulates that policy-making currently exercised in Brussels in those areas of devolved competence will not in the first instance be automatically transferred to the devolved nations. Instead, the EUWB provides for the UK Government to review those powers and, 
where it deems it appropriate, to devolve them back to Scotland, Wales and Northern Ireland. The Scottish Parliament and Welsh Assembly, and their Westminster MPs, dubbed this manoeuvre a 'power grab' and sought to amend the relevant provisions of the EUWB. While the Welsh Assembly eventually gave its consent to the Bill the Scottish Parliament refused to do so, although constitutionally it was unable to prevent the UK Parliament from adopting the EUWB.

21 As this constitutional dispute has rumbled on, the UK Government has been working with the devolved administrations via the Joint Ministerial Committee (JMC), the body used to coordinate cross-national policies, to try to establish at which level competence should be exercised for environmental, agriculture and fisheries policies. However, the JMC is not well-regarded by the devolved administrations. It meets irregularly at the behest of the UK Government, which typically sets the agenda with little scope for meaningful input from the devolved nations. It is also an opaque institution, which raises questions about transparency and the ability of stakeholders to influence the design of future policy. These weaknesses were highlighted in March 2018 when the UK Government published ${ }^{35}$ a list of 153 policy areas upon which cross-UK coordination maybe required: it suggested that 49 of them would require no common frameworks, 82 would need non-legislative frameworks and 24 (including agriculture, chemicals and pesticides) would require UKwide legislative frameworks. There was no input from stakeholders in drawing up the list, which does not have the backing of the Scottish and Welsh Governments. Indeed, the Scottish Government has complained that in those 24 areas Scotland may be restricted on legislating for up to 7 years. ${ }^{36}$ Moreover, the proposed new environmental watchdog would only cover England, which raises the prospect of further divergence in policymaking implementation and enforcement regimes within the UK.

\section{Deliberate Policy Retrenchment}

The final area of concern, articulated both at UK and EU levels, is the fear that the Government will either deliberately roll back environmental standards or simply fail to prioritise the environment so that policy stagnates. Michel Barnier, ${ }^{37}$ the EU's chief negotiator, has made clear that the EU wishes to see an environmental non-regression principle included in any future EU-UK trade deal to mitigate the risk that the UK will weaken standards to secure a competitive advantage. A new advocacy group, Greener UK, has brought together all the key environmental non-governmental organisations (ENGOs) to present a united front and to lobby government on the priorities for post-Brexit environmental governance. Greener UK has prioritised trying to guarantee, at a minimum, the same level of protection for the environment post-Brexit in response to widespread apprehension that the Government will weaken standards. It is worth noting here that because the $\mathrm{EU}$ is a hyper-consensual polity - to become law, proposals require agreement from the European Commission, the Council of the European Union and the European Parliament - it is difficult to secure agreement and even harder to roll back policy once it has been adopted. ${ }^{38}$ Whilst this system has its disadvantages (i.e. suboptimal policies can be difficult to change) from an environmental perspective one advantage is that EU policy typically has longer time horizons and is more stable than much domestic policy. After departing the EU it will, in principle, be easier for UK environmental policies to be amended, so ENGOs are concerned that policies may become subjected to change. For areas like renewable energy and climate change the prospect of such uncertainty may have a chilling effect upon future investment, ${ }^{39}$ and there is 
widespread apprehension about the implications of Brexit for key policy sectors such as the chemicals industry, where participation in the single Market requires the implementation of EU rules. ${ }^{40}$

The Government has been keen to assuage such fears, Prime Minister May declared that in "areas like workers' rights or the environment, the EU should be confident that we will not engage in a race to the bottom in the standards and protections we set. There is no serious political constituency in the UK which would support this - quite the opposite". ${ }^{41}$ To shore up the Government's environmental credentials May made the astute move of appointing Michael Gove as her Environment Secretary. Gove, a leading Brexiteer, is a dynamic politician who has brought much-needed energy and drive to the role. Gove has been keen to stress that the UK can secure a "Green Brexit" with no weakening of environmental or animal welfare standards. ${ }^{42}$ In January 2018 Defra published its 25 Year Environment Plan spelling out the Government's priorities in the immediate and longer term ${ }^{43}$ and during a farming consultation in Spring 2018 the Government committed to greening post-Brexit agriculture policy and to delivering a 'public money for public goods' approach in which public goods are broadly conceived to be environmental. ${ }^{44}$ In addition, as noted above, the Government launched a principles and governance consultation ${ }^{45}$ and the EUWB was amended to secure the drafting of an environmental principles bill in the near future.

Yet, set against these positive developments are various statements made by key Government ministers. For example, during the referendum campaign George Eustice, the current farming minister, described the habitats and birds directives as 'spirit crushing' and said they would 'go' post-Brexit. ${ }^{46}$ Boris Johnson, Foreign Secretary, implied in February 2018 that Brexit provided the opportunity to weaken planning rules and legislation protecting nature. ${ }^{47}$ Gove himself argued in March 2017, prior to his appointment as Environment Secretary, that the habitats and birds directives should be reformed or rescinded post Brexit. ${ }^{48}$ One of May's first moves as Prime Minister was to disband the Department for Energy and Climate Change, merging the energy and climate portfolios into a new Department for Business, Energy and Industrial Strategy. Such sentiments have fuelled on-going scepticism about the Government's willingness to deliver its promised Green Brexit. Moreover, even if there is a willingness to secure a 'Green Brexit' there are on-going capacity challenges because Defra has been profoundly weakened by austerity-inspired staffing cuts. ${ }^{49}$ While Defra is now rapidly recruiting staff to deal with the Brexit workload it is still relatively understaffed given the challenges involved, ${ }^{50}$ raising the risk of what the Environmental Audit Committee has called policy "zombification". ${ }^{51}$ This term refers to the prospect of policies being copied onto the UK statute book via the EUWB but through lack of time or staff, not being updated or properly implemented, so policies would technically be alive in a legal sense, but effectively dead - or zombie-like - in day-to-day practice. ${ }^{52}$

An increased politicisation of environmental issues could offset this risk. Although the environment had low salience during the referendum and election campaigns, age emerged as key cleavage underpinning both results. Young people were much more likely to support staying in the $\mathrm{EU}^{53}$ and in the 2017 general election younger voters (below 45) were more likely to vote Labour - resulting in its much improved performance - while older voters (over 60 ) were more likely to vote Conservative. ${ }^{54}$ Media commentary suggested that the publication of the Government's 25 Year Environment Plan (YEP) had in part been prompted by the Conservative Party trying to attract younger voters who 
had voted Labour in the general election. ${ }^{5}$ Indeed, there have been several green initiatives that appear to be part of a deliberate strategy to woo back younger voters, including May's decision to back down on the Conservative manifesto promise to hold a parliamentary vote on lifting the ban on fox hunting and Gove's measures to ban the sale of ivory products, plant 50 million trees and introduce a plastic bottle deposit scheme. ${ }^{56}$ It remains to be seen how committed the Conservatives are to this strategy; certainly the publication of the YEP prompted a former advisor to May to argue that the environment was not natural territory for the Conservative Party and that it should be investing its energies elsewhere. ${ }^{57}$

The Labour Party has been prepared to use the environment as part of its critique of Government policy on Brexit, ${ }^{58}$ but it remains divided on Brexit more generally and has made no concerted effort to take ownership of the environmental issue. However, Sadiq Khan, the Labour Mayor of London has sought to make political capital over the on-going air quality issue. ${ }^{59}$ The UK Government has been successfully prosecuted and referred to the CJEU for failing to implement the EU's ambient air quality laws, with London blighted by particularly poor air quality. Any attempt by the Government to weaken air quality standards post-Brexit would provide a golden opportunity for Khan to embarrass the Government. However, it seems like much of the heavy lifting involved in keeping environmental policy in the public eye and high up the policy agenda will be done by ENGOs, who will face a post-Brexit resource challenge as many have benefitted from pooled capacity at the EU level and from funding from the European Commission.

\section{Conclusion}

Brexit raises the prospect of a fundamental destabilisation of the UK's environmental policy sector. After an initial struggle with the EU's way of doing business the UK acclimatised itself to the EU and became an active participant in decision making and a leader on climate change. However, as the economic crisis took hold and the UK Government embraced an austerity agenda, EU environmental policy became the focus of negative political rhetoric from the political right. Consequently, the Conservative Government's claims that it wants a 'Green Brexit' have been treated with a degree of scepticism. Certainly there has been considerable activity in the environmental policy sector where the energetic Environment Secretary, Michael Gove, has tried to make a success of his brief, bringing forward several major policy pronouncements and consultations in the first half of 2018 with the intention of establishing the planks for a 'Green Brexit'. However, the negative statements of key cabinet members (including Gove), the major capacity challenges facing Defra and the destabilisation of the UK's constitutional settlement with environmental policy at the centre of an on-going dispute between the UK and Scottish Governments, all suggest that the environment is in for a rocky ride. The EU's preference for a non-regression principle, business pressure to maintain a stable policy regime and the on-going advocacy of Greener UK may help to counter these negative pressures. However, the overall impact of the UK's departure from an organisation that has made environmental leadership part of its identity is very likely to involve some dampening of British policy ambition. Conversely, the loss of the UK's role as a climate leader from the Council is a significant negative consequence of Brexit for the EU. 
Charlotte Burns is Professor of Sustainable Growth at the University of Sheffield and is a co-chair of the Brexit and Environment network. Neil Carter is Professor of Politics at the University of York. He has published widely on environmental politics and policy. The 3rd edition of his book The Politics of the Environment: Ideas, Activism, Policy (Cambridge University Press), was published in July 2018.

\section{BIBLIOGRAPHY}

BBC, 13 June 2018, https://www.bbc.co.uk/news/uk-politics-44467306 [accessed 26 June 2018].

Burns, Charlotte, The EU Referendum and the Environment, (London, Friends of the Earth, 2015), available at: https://friendsoftheearth.uk/sites/default/files/downloads/eu-referendumenvironment-81600.pdf

Burns, Charlotte [and 13 others, The EU Referendum and the UK Environment: An Expert Review (2016), http://ukandeu.ac.uk/research-papers/eu-referendum-and-uk-environment-expert-review/ [accessed 2 July 2018].

Burns, Charlotte, Gravey, Viviane and Jordan, Andrew UK Environmental Policy Post-Brexit: A Risk Analysis (London, Friends of the Earth, 2018), available at: https://cdn.friendsoftheearth.uk/ sites/default/files/downloads/Environment\%20and\%20Brexit\%2C\%20C\%20Burns\%20Et\%20al\%2C \%20March\%202018\%20web_0.pdf

BusinessGreen, 28 March 2017 https://www.businessgreen.com/bg/news/3007263/michael-govetakes-aim-at-habitats-directive [accessed 26 June 2018].

BusinessGreen, 14 February 2018 https://www.businessgreen.com/bg/news/3026668/borisjohnson-hints-at-opportunity-to-dilute-environmental-standards-post-brexit [accessed 26 June 2018].

Cabinet Office, Frameworks analysis - Breakdown of areas of EU law that intersect with devolved competence in Scotland, Wales and Northern Ireland (London, Cabinet Office, 9 March 2018), https:// assets.publishing.service.gov.uk/government/uploads/system/uploads/attachment_data/ file/686991/20180307_FINAL__Frameworks_analysis_for_publication_on_9_March_2018.pdf Carter, Neil, "The Party Politicisation of the Environment in Britain", Party Politics, 12(6), 2006, pp.747-67.

Carter, Neil and Clements, Ben, "From 'Greenest Government Ever' to 'Get Rid of All the Green Crap': David Cameron, the Conservatives and the Environment”, British Politics, 10(2), 2015, pp.204-225.

Carter, Neil and Jacobs, Michael, "Explaining Radical Policy Change: The Case of Climate Change and Energy Policy Under the British Labour Government 2006-10”, Public Administration, 92(1), 2014, pp.125-141.

Carter, Neil and Lowe, Philip, 'Environmental Politics and Administrative Reform', Political Quarterly, 65(3), 1994, pp. 263-74. 
Clarke, Harold, Goodwin, Matthew and Whiteley, Paul, Brexit: Why Britain Voted to Leave the European Union (Cambridge University Press, 2017).

Cowell, Richard and Owens, Susan, "Land Use Planning", in Charlotte Burns et al., The EU Referendum and the UK Environment: An Expert Review (2016), pp.57-67, available at: http:// environmenteuref.blogspot.co.uk/p/the-report.html.

Defra, Health and Harmony: the Future for Food, Farming and the

Environment in a Green Brexit (London, Cm 9577, February 2018), available at: https:// assets.publishing.service.gov.uk/government/uploads/system/uploads/attachment_data/ file/684003/future-farming-environment-consult-document.pdf.

Defra, Environmental Principles and Governance after the United Kingdom leaves the European Union, Consultation on environmental principles and accountability for the environment (London, Defra, May 2018), available at: https://consult.defra.gov.uk/eu/environmental-principles-and-governance/ supporting_documents/Environmental\%20Principles\%20and\%20Governance\%20after\%20EU\% 20Exit\%20\%20Consultation\%20Document.pdf

Environment Audit Committee, The Future of the Natural Environment after the EU Referendum (House of Commons, HC599, $6^{\text {th }}$ Report, Session 2016-17).

Environmental Audit Committee, The Future of Chemicals Regulation after the EU Referendum (House of Commons, HC 912, 11th Report, Session 2016-17).

Environmental Audit Committee, Green Finance: Mobilising Investment in Clean Energy and Sustainable Development, (House of Commons, HC 617, 6th Report, Session 2017-19).

Euractiv, 11 April 2018 https://www.euractiv.com/section/energy-environment/news/eu-willseek-non-regression-clause-to-tie-uk-to-environmental-standards/ [accessed 22 June 2018].

European Communities Act 1972, available at: https://www.legislation.gov.uk/ukpga/1972/68/ contents

Gove, Michael, “The Unfrozen Moment - Delivering a Green Brexit” (speech, 21 July 2017) available at: https://www.gov.uk/government/speeches/the-unfrozen-moment-delivering-agreen-brexit [accessed 26 June 2018].

Gravey, Viviane and Jordan, Andrew, "Does the European Union have a Reverse Gear? Policy Dismantling in a Hyperconsensual Polity", Journal of European Public Policy, 23 (8), 2016, pp.1180-1198.

Guardian, The, 20 March 2012 https://www.theguardian.com/environment/blog/2012/mar/20/ red-tape-challenge-environmental-regulations [accessed 26 June 2018].

The Guardian, 11 November 2015 https://www.theguardian.com/environment/2015/nov/11/ defra-hit-by-largest-budget-cuts-of-any-uk-government-department-analysis-shows [accessed 22 June 2018].

The Guardian, 30 May 2016 https://www.theguardian.com/politics/2016/may/30/brexit-spiritcrushing-green-directives-minister-george-eustice [accessed 26 June 2018].

Guardian, The, 4 May 2018 https://www.theguardian.com/politics/2018/may/04/brexitimpossible-challenge-for-environment-and-trade-departments [accessed 2 July 2018].

Guardian, The, 10 May 2018 https://www.theguardian.com/environment/2018/may/10/newwatchdog-to-protect-environment-after-brexit-gove-announces [accessed 2 July 2018].

Guardian, The, 12 May 2018 https://www.theguardian.com/environment/2018/may/12/peers-torebel-over-toothless-environment-watchdog-brexit [accessed 22 June] 
HM Government, Report of the Habitats and Wild Birds Directives Implementation Review (London, Defra, 2012), available at: https://www.gov.uk/government/publications/report-of-the-habitatsand-wild-birds-directives-implementation-review.

HM Government, A Green Future: Our 25 Year Plan to Improve the Environment (London, Defra, 2018), available at: https://www.gov.uk/government/uploads/system/uploads/attachment_data/ file/673203/25-year-environment-plan.pdf.

Hogarth, Raphael and Lloyd, Lewis, Who's Afraid of the ECJ? Charting the UK's Relationship with the European Court (London, Institute for Government, 2017), available at: https:// www.instituteforgovernment.org.uk/sites/default/files/publications/IfG_Brexit_ECJ_v10FINAL\% 20web.pdf

House of Commons 2018, European Union Withdrawal Bill, Commons amendments in lieu, amendments to amendments and reasons. Available from https://publications.parliament.uk/ pa/bills/lbill/2017-2019/0111/18111.pdf\#page=3.

House of Commons Library, European Union Withdrawal Bill (Briefing Paper CBP-8079, 1 September 2017) available at: https://researchbriefings.parliament.uk/ResearchBriefing/Summary/ CBP-8079\#fullreport

Independent, The, 2 June 2016, https://www.independent.co.uk/news/uk/politics/eu-referendumwildlife-groups-rspb-wwf-uk-back-remain-a7060231.html [consulted 22 June 2018].

Institute for European Environmental Policy, Brexit - the Implications for UK Environmental Policy and Regulation (London, IEEP, 2016), available at: https://ieep.eu/archive_uploads/2016/ IEEP_2016_Brexit_-_Implications_for_UK_Environmental_Policy_and_Regulations.pdf

Institute for Government, "EU Withdrawal Bill Amendments and Debates" (London, 2018), available at: https://www.instituteforgovernment.org.uk/explainers/eu-withdrawal-billamendments-and-debates.

Jordan, Andrew, "Private Affluence and Public Squalor. The Europeanisation of British Coastal Bathing Water", Policy and Politics, 26(1), 1998, pp. 33-54.

Jordan, Andrew, The Europeanization of British Environmental Policy, A Departmental Perspective, (Basingstoke: Palgrave Macmillan, 2002).

Jordan, Andrew, “The United Kingdom: From Policy 'Taking' to Policy 'Shaping'”, in Andrew. Jordan and Duncan Liefferink (eds.), Environmental Policy in Europe: The Europeanization of National Environmental Policy (London, Routledge, 2004), pp. 205-223.

Jordan, Andrew, Burns, Charlotte and Gravey, Viviane, "Three Brexit governance gaps no one is talking about” (London, Green Alliance blog, 6 December 2017), available at: https:// greenallianceblog.org.uk/2017/12/06/three-brexit-governance-gaps-no-one-is-talking-about/ \#more-11126 [accessed 26 June 2018].

Jordan, Andrew, Burns, Charlotte and Gravey, Viviane “Zombie-like or Servile?", Transform (11 August 2016) available at: https://transform.iema.net/article/zombie-or-servile [accessed 26 June 2018].

Khan, Sadiq, “Mayor of London Sadiq Khan's response to Government Air Quality Plan” (26 July 2017) available at: https://www.london.gov.uk/press-releases/mayoral/response-togovernment-air-quality-plan [accessed 30 June 2018].

Labour List, 27 November 2016, http://labourlist.org/2016/11/keir-starmer-hard-brexit-poses-anew-threat-to-our-environment/ [accessed 30 June 2018]. 
Lee, Maria and Fischer, Liz, "Environmental governance after the EU: the need to ensure accountability”, (blog, 28 November 2016) available at: https:// www.brexitenvironment.co.uk/2016/11/28/environmental-governance-after-the-eu-the-needto-ensure-accountability/ [accessed 22 June 2018].

Mail, Daily, 20 January 2018, http://www.dailymail.co.uk/news/article-5325071/Nick-Timothywarns-Tories-splash-cash.html [accessed 22 June 2018].

May, Theresa, "PM speech on our future economic partnership with the European Union", 2 March 2018, available from: https://www.gov.uk/government/speeches/pm-speech-on-ourfuture-economic-partnership-with-the-european-union [accessed 30 June 2018].

Morris, R., 2011. 'The application of the Habitats Directive in the UK: Compliance or gold Plating?', Land Use Policy, 28(1): 361-369.

National Audit Office, Implementing the UK's Exit from the European Union: The Department for Environment, Food \& Rural Affairs (London, HC 647 Session 2017-2019, 20 December 2017), available at: https://www.nao.org.uk/press-release/implementing-the-uks-exit-from-the-europeanunion-the-department-for-environment-food-rural-affairs/

Prosser, Chris, Fieldhouse, Ed, Green Jane and Evans, Geoff, "The Myth of the 2017 Youthquake Election", 29 January 2018, available at: http://www.britishelectionstudy.com/bes-impact/themyth-of-the-2017-youthquake-election/\#.WzKu1adKiUl.

Rayner, Tim. and Jordan, Andrew, “The United Kingdom: a Record of Leadership Under Threat”, in Rudiger Wurzel, James Connelly and Duncan Liefferink (eds.), The European Union in International Climate Change Politics: Still Taking a Lead? (London: Routledge, 2017), pp.173-188.

Royles, Elin. and McEwen, Nicola, "Empowered for Action? Capacities and Constraints in Substate Government Climate Action in Scotland and Wales", Environmental Politics, 24 (6), 2015, pp.1034-1054.

Steffani, Sara and Cooper, Charlie, "The Greenwashing of Theresa May”, Politico, 1 October 2018, available at: https://www.politico.eu/article/the-greenwashing-of-theresa-may/. [accessed 10 January 2018].

The Telegraph, 20 September 2012, https://www.telegraph.co.uk/finance/yourbusiness/9556541/ Michael-Fallon-ready-to-light-bonfire-of-red-tape.html [accessed 26 June 2018].

\section{NOTES}

1. When the UK joined what we now know as the European Union it was called the European Economic Community, and then the European Communities before becoming the EU in 1993. For the purposes of consistency the term EU will be used throughout.

2. National Audit Office, Implementing the UK's Exit from the European Union: The Department for Environment, Food \& Rural Affairs (London, HC 647 Session 2017-2019, 20 December 2017); also see The Guardian 4 May 2018, https://www.theguardian.com/politics/2018/may/04/brexitimpossible-challenge-for-environment-and-trade-departments;

3. Charlotte Burns, The EU Referendum and the Environment (London, Friends of the Earth, 2015), https://friendsoftheearth.uk/sites/default/files/downloads/eu-referendum-

environment-81600.pdf; Charlotte Burns et al. (eds.), The EU Referendum and the UK Environment: An Expert Review; available at: http://ukandeu.ac.uk/research-papers/eu-referendum-and-ukenvironment-expert-review/; Charlotte Burns, Viviane Gravey and Andrew Jordan, UK Environmental Policy Post-Brexit: A Risk Analysis (London, Friends of the Earth, 2018), https:// 
cdn.friendsoftheearth.uk/sites/default/files/downloads/Environment\%20and\%20Brexit\%2C\%

20C\%20Burns\%20Et\%20al\%2C\%20March\%202018\%20web_0.pdf; Institute for European Environmental Policy, Brexit - the Implications for UK Environmental Policy and Regulation (2016), https://ieep.eu/archive_uploads/2016/

IEEP_2016_Brexit_Implications_for_UK_Environmental_Policy_and_Regulations.pdf.

4. Andrew Jordan, The Europeanization of British Environmental Policy: A Departmental Perspective (Basingstoke: Palgrave Macmillan, 2002).

5. Neil Carter, and Philip Lowe, "Environmental Politics and Administrative Reform", Political Quarterly 65(3), 1994, pp. 263-74.

6. Now known as the Department for Environment Food and Rural Affairs (Defra).

7. Andrew Jordan, "Private Affluence and Public Squalor. The Europeanisation of British Coastal Bathing Water", Policy and Politics 26(1), 1998, pp. 33-54.

8. Jordan, Europeanization of British Environmental Policy.

9. Andrew Jordan, “The United Kingdom. From Policy ‘Taking' To Policy ‘Shaping”, in Andrew Jordan and Duncan Liefferink (eds.), Environmental Policy in Europe: The Europeanization of National Environmental Policy (London: Routledge, 2004), pp. 205-223.

10. Tim Rayner and Andrew Jordan, "The United Kingdom: a Record of Leadership under Threat", in Rudiger Wurzel, James Connelly and Duncan Liefferink (eds.), The European Union in International Climate Change Politics: Still Taking a Lead? (London: Routledge, 2017), pp. 173-188.

11. Jordan, Europeanization of British Environmental Policy.

12. Richard Cowell, and Susan Owens, "Land Use Planning", in Burns et al., The EU Referendum and the UK Environment, pp. 57-67

13. Neil Carter, "The Party Politicisation of the Environment in Britain", Party Politics 12(6), 2006, pp. 747-67.

14. Neil Carter and Michael Jacobs, "Explaining Radical Policy Change: The Case of Climate Change and Energy Policy Under the British Labour Government 2006-10", Public Administration 92(1), 2014, pp. 125-141.

15. Ibid., p. 130.

16. Ibid., pp. 132-133.

17. Ibid., p. 136.

18. Neil Carter and Ben Clements, "From 'Greenest Government Ever' to 'Get Rid of All the Green Crap': David Cameron, the Conservatives and the Environment", British Politics 10(2), 2015, pp. 204-225.

19. Ibid., pp. 216-217.

20. HM Government, Report of the Habitats and Wild Birds Directives Implementation Review (London, Defra, 2012), available at: https://www.gov.uk/government/publications/report-of-the-habitatsand-wild-birds-directives-implementation-review.

21. Ibid.; Roger Morris, "The Application of the Habitats Directive in the UK: Compliance or Gold Plating?", Land Use Policy 28(1), 2011, pp. 361-369.

22. The Guardian, 20 March 2012, https://www.theguardian.com/environment/blog/2012/ mar/20/red-tape-challenge-environmental-regulations [accessed 26 June 2018]; The Telegraph, 20 September 2012, https://www.telegraph.co.uk/finance/yourbusiness/9556541/Michael-Fallonready-to-light-bonfire-of-red-tape.html [accessed 26 June 2018].

23. The Independent, 2 June 2016, https://www.independent.co.uk/news/uk/politics/eureferendum-wildlife-groups-rspb-wwf-uk-back-remain-a7060231.html [accessed 22 June 2018].

24. European Communities Act 1972, available at: https://www.legislation.gov.uk/ ukpga/1972/68/contents

25. House of Commons Library, European Union Withdrawal Bill (Briefing Paper CBP-8079, 1 September 2017) available at: https://researchbriefings.parliament.uk/ResearchBriefing/ Summary/CBP-8079\#fullreport 
26. House of Commons, European Union (Withdrawal) Bill, Commons amendments in lieu, amendments to amendments and reasons, available from: https://publications.parliament.uk/ pa/bills/lbill/2017-2019/0111/18111.pdf\#page=3.

27. Institute for Government, "EU Withdrawal Bill Amendments and Debates" (London, 2018), available at: https://www.instituteforgovernment.org.uk/explainers/eu-withdrawal-billamendments-and-debates.

28. Andrew Jordan, Charlotte Burns, and Viviane Gravey, "Three Brexit governance gaps no one is talking about" (London, Green Alliance blog, 6 December 2017), available at: https:// greenallianceblog.org.uk/2017/12/06/three-brexit-governance-gaps-no-one-is-talking-about/ \#more-11126 [accessed 26 June 2018].

29. Ibid.; Maria Lee and Liz Fisher, "Environmental governance after the EU: the need to ensure accountability" (blog, 28 November 2016) available at: https:// www.brexitenvironment.co.uk/2016/11/28/environmental-governance-after-the-eu-the-needto-ensure-accountability/ [accessed 22 June 2018].

30. Raphael Hogarth and Lewis Lloyd, Who's Afraid of the ECJ? Charting the UK's Relationship with the European Court (London, Institute for Government, 2017).

31. Defra, Environmental Principles and Governance after the United Kingdom Leaves the European Union, Consultation on Environmental Principles and Accountability for the Environment (London, Defra, May 2018).

32. The Guardian, 10 May 2018, available at: https://www.theguardian.com/environment/2018/ may/10/new-watchdog-to-protect-environment-after-brexit-gove-announces.

33. The Guardian, 12 May 2018, https://www.theguardian.com/environment/2018/may/12/ peers-to-rebel-over-toothless-environment-watchdog-brexit [accessed 22 June 2018]

34. Elin Royles and Nicola McEwen, "Empowered for Action? Capacities and Constraints in Substate Government Climate Action in Scotland and Wales", Environmental Politics 24 (6), 2015, pp. 1034-1054.

35. Cabinet Office, Frameworks analysis - Breakdown of areas of EU law that intersect with devolved competence in Scotland, Wales and Northern Ireland (London, Cabinet Office, 9 March 2018), https:// assets.publishing.service.gov.uk/government/uploads/system/uploads/attachment_data/ file/686991/20180307_FINAL__Frameworks_analysis_for_publication_on_9_March_2018.pdf 36. BBC, 13 June 2018, https://www.bbc.co.uk/news/uk-politics-44467306 [accessed 26 June 2018]. 37. Euractiv, 11 April 2018, available at: https://www.euractiv.com/section/energy-environment/ news/eu-will-seek-non-regression-clause-to-tie-uk-to-environmental-standards/ [accessed 22 June 2018].

38. Viviane Gravey and Andrew Jordan, "Does the European Union have a Reverse Gear? Policy Dismantling in a Hyperconsensual Polity", Journal of European Public Policy 23 (8), 2016, pp. 1180-1198.

39. Environmental Audit Committee, Green Finance: Mobilising Investment in Clean Energy and Sustainable Development, (House of Commons, HC 617, Sixth Report, Session 2017-19, 16 May 2018). 40. Environmental Audit Committee, The Future of Chemicals Regulation after the EU Referendum (House of Commons, HC 912, Eleventh Report, Session 2016-17).

41. Theresa May, "Our Future Economic Partnership with the European Union" (speech, 2 March 2018), available at: https://www.gov.uk/government/speeches/pm-speech-on-our-futureeconomic-partnership-with-the-european-union [accessed 30 June 2018].

42. Michael Gove, "The Unfrozen Moment - Delivering a Green Brexit" (speech, 21 July 2017) available at: https://www.gov.uk/government/speeches/the-unfrozen-moment-delivering-agreen-brexit [accessed 26 June 2018].

43. HM Government, A Green Future: Our 25 Year Plan to Improve the Environment (London, Defra, 2018), available at: https://www.gov.uk/government/uploads/system/uploads/ attachment_data/file/673203/25-year-environment-plan.pdf. 
44. Defra, Health and Harmony: the Future for Food, Farming and the Environment in a Green Brexit (London, Cm 9577, February 2018).

45. Defra, Environmental Principles and Governance.

46. The Guardian, 30 May 2016, https://www.theguardian.com/politics/2016/may/30/brexitspirit-crushing-green-directives-minister-george-eustice [accessed 26 June 2018].

47. BusinessGreen, 14 February 2018, https://www.businessgreen.com/bg/news/3026668/borisjohnson-hints-at-opportunity-to-dilute-environmental-standards-post-brexit [accessed 26 June 2018].

48. BusinessGreen, 28 March 2017, https://www.businessgreen.com/bg/news/3007263/michaelgove-takes-aim-at-habitats-directive [accessed 26 June 2018].

49. The Guardian, 11 November 2015, https://www.theguardian.com/environment/2015/nov/11/ defra-hit-by-largest-budget-cuts-of-any-uk-government-department-analysis-shows [accessed 22 June 2018].

50. The Guardian, 4 May 2018, https://www.theguardian.com/politics/2018/may/04/brexitimpossible-challenge-for-environment-and-trade-departments [accessed 26 June 2018].

51. Environment Audit Committee, The Future of the Natural Environment after the EU Referendum (House of Commons, HC599, $6^{\text {th }}$ Report, Session 2016-17).

52. Andy Jordan, Charlotte Burns, and Viviane Gravey, "Zombie-like or Servile?", Transform, available at: https://transform.iema.net/article/zombie-or-servile [accessed 26 June 2018].

53. Harold Clarke, Matthew Goodwin and Paul Whiteley, Brexit: Why Britain Voted to Leave the European Union (Cambridge, Cambridge University Press, 2017), pp. 154-155.

54. Chris Prosser, Ed Fieldhouse, Jane Green and Geoff Evans, "The Myth of the 2017 Youthquake Election", (British Election Study, 29 January 2018) http://www.britishelectionstudy.com/besimpact/the-myth-of-the-2017-youthquake-election/\#.WzKu1adKiUl.

55. Sara Stefanini and Charlie Cooper, "The Greenwashing of Theresa May", Politico, 1 October 2018, https://www.politico.eu/article/the-greenwashing-of-theresa-may/ [accessed 10 January 2018].

56. Ibid.

57. Daily Mail, 20 January 2018, available at: http://www.dailymail.co.uk/news/article-5325071/ Nick-Timothy-warns-Tories-splash-cash.html [accessed 22 June 2018].

58. Labour List, 27 November 2016, available at: http://labourlist.org/2016/11/keir-starmer-hardbrexit-poses-a-new-threat-to-our-environment/ [accessed 30 June 2018].

59. Sadiq Khan, "Mayor of London Sadiq Khan's response to Government Air Quality Plan", available at: https://www.london.gov.uk/press-releases/mayoral/response-to-government-airquality-plan [accessed 30 June 2018].

\section{ABSTRACTS}

In 2016 the United Kingdom (UK) voted in a referendum to leave the European Union (EU). Whilst the environment did not feature significantly in the referendum campaign it has emerged as a major focus for the UK Government as it prepares for Brexit. Since the UK joined the EU in 1973, its approach to environmental policy-making has been profoundly shaped by processes of Europeanisation. Consequently, disentangling the UK from the environmental acquis communautaire will be a huge undertaking. Whilst the Government has committed to the pursuit 
of a 'Green Brexit' there are on-going concerns that Brexit will lead to weaker environmental ambition and governance. It may also produce policy divergence across the UK as the environmental sector is devolved and has become a site of constitutional conflict over the powers of the devolved nations of Scotland, Wales and Northern Ireland. A once stable policy area characterised by a broad cross-party and cross-national consensus therefore is, post-Brexit, increasingly likely to become a focus for constitutional and party political conflict and competition.

En 2016, le Royaume Uni a choisi par référendum de quitter l'Union Européenne. Bien que l'environnement ait été un sujet mineur lors de la campagne, cette question est depuis apparue comme une dimension très importante de la sortie de l'UE. Depuis que le Royaume-Uni a rejoint l'Union Européenne en 1973, son mode de gestion politique des questions environnementales a été profondément influencé par les processus d'européanisation. L'intégration et l'adaptation de l'acquis communautaire dans ce domaine représentent par conséquent une tâche extrêmement complexe. Si le gouvernement britannique s'est engagé à mettre en place un "Brexit vert ", de nombreux acteurs s'inquiètent d'un affaiblissement de la gouvernance et des ambitions environnementales britanniques. Le Brexit pourrait également mener à une fragmentation des politiques environnementales à travers le Royaume-Uni, car il s'agit là d'un point important du débat constitutionnel relatif aux pouvoirs respectifs de l'Ecosse, du pays de Galles et de l'Irlande $\mathrm{du}$ Nord. Alors que l'environnement constituait un domaine politique relativement stable et consensuel, cette question est donc amenée à devenir, après le Brexit, beaucoup plus conflictuelle et caractérisée par une intensification des antagonismes entre les différents partis et nations dus Royaume-Uni.

\section{INDEX}

Mots-clés: Brexit, gouvernement Conservateur, dévolution, gouvernance environnementale, environnement, politique environnementale britannique

Keywords: Brexit, Conservative Government, devolution, environmental governance, environment, UK environmental policy

\section{AUTHORS}

\section{CHARLOTTE BURNS}

Professor of Sustainable Growth, University of Sheffield

\section{NEIL CARTER}

Professor of Politics, University of York. 